\title{
AN INSIGHT INTO THE MALAYSIAN TAKE-OVERS AND MERGERS CODE 2016
}

\author{
Mushera Ambaras Khan*
}

\section{INTRODUCTION}

The law governing takeovers and mergers in Malaysia was recently revised with the introduction of the Malaysian Take-Overs and Mergers Code 2016 which came into force on $15^{\text {th }}$ August 2016 ('the 2016 Code'). The 2016 Code replaced the Take- Overs and Mergers Code 2010, providing a totally new outlook on the regulatory framework. Along with the new Code, the Securities Commission also introduced a rule book, Rules on Take-Overs and Mergers and Compulsory Acquisitions (The Rules) with effect from the 15th of August 2016, issued as guidelines under the Capital Market and Services Act 2007. The Rules set out the operative provisions applicable for various aspects of takeovers. Despite the major changes made on the structure of the new Code, the foundation of the law remains the same with the earlier Codes. This commentary will focus on the framework of the new Code and the new approach adopted in interpreting the Code as guided by the Rules on Take-Overs and Mergers and Compulsory Acquisitions. The Rules are intended to be aligned to newer developments in the capital markets. ${ }^{1}$ The 2016 Code is simplified into 16 provisions which, among others, prescribe 12 broad-based principles consisting of standards of corporate practices to be observed in takeover transactions. ${ }^{2}$ In line with the efforts by the Securities Commission to move towards a proportionate regulatory regime, the enhancements of the law seek to ensure that the takeover framework will be facilitative to commercial realities while providing protection to shareholders, where required. ${ }^{3}$

Professor, Department of Civil Law, Ahmad Ibrahim Kulliyyah of Laws, International Islamic University Malaysia. Email: mushera@iium.edu.my.

1 The amendments made to the Capital Market and Services Act in 2015 reflect a more dynamic regulatory environment for takeovers.

2 The 2010 Code was more complex as it provides the detailed rules relating to takeovers and mergers. The current Code is more principled-based; the detailed rules are now found in The Rules.

3 https://www.sc.com.my/post_archive/sc-introduces-rule-book-in-revisedframework-on-takeovers-and-mergers/. 


\section{APPLICATION OF THE 2016 CODE}

The 2016 Code is far more concise compared to all the previous Codes on takeovers and mergers. It is drawn on broad-based principles and serves as a main guidance for those involved in takeovers and mergers transactions. The Code and the Rules apply to takeovers and mergers of any listed corporation and any company or entity specified in the Rules. ${ }^{4}$ The Rules provide for the details and technicalities cascading from the general principles embedded in the Code. The Capital Market and Services Act 2007 ('CMSA') defines "company", to mean a public company whether or not it is listed on any stock exchange. ${ }^{5}$ Unlike the previous position, not all unlisted public companies are subjected to the Code. The Rules define a "company" to which the Code applies to include only an unlisted public company having more than 50 shareholders and net assets of RM15 million or more. Previously, all unlisted public companies were subjected to the Securities Commission's rulings if they are involved in takeovers. The Code also applies to a business trust and a real estate investment trust (REIT) that are listed in Malaysia. ${ }^{6}$ While the 2010 Code was silent, the Rules now provide guidance on the treatment of target companies which have listings in dual jurisdictions. ${ }^{7}$ In respect of a target with primary listing on both, a stock exchange in Malaysia and outside of Malaysia, the target may be subject to the dual jurisdiction of the Securities Commission and the foreign takeovers regulator. Where the target has a primary listing on a stock exchange outside of Malaysia and a secondary listing in Malaysia, the Rules provide that the Securities Commission may consider disapplying the Rules provided that the applicant is able to demonstrate that the relevant takeover regulation in the foreign jurisdiction accords an equivalent level of protection to the shareholders of the target as provided under the Rules.

Following the approach of the 2010 Code, the revised 2016 Code applies to takeovers and mergers effected by means of a trust scheme,

1.06 , the Rules.

Section 217(1)(b) of the CMSA 2007.

1.08 , The Rules.

The inclusion of treatment of target companies which has listings in dual jurisdictions is meant to provide guidance for the many companies that are currently having listings in dual jurisdictions. 
a scheme of arrangement, ${ }^{8}$ compromise, amalgamation or selective capital reduction and repayment. The 2010 Code, out of concern for the lack of protection for minority shareholders, for the first time, regulated the schemes for amalgamation and selective capital reduction. The increasing trend in mergers and acquisitions activities has witnessed a variety of techniques used for shifting control of a company. Through share acquisition effected via schemes or even selective capital reduction, control of a company may move from an existing controlling shareholder to another or from the management of the target company to the acquirer. ${ }^{9}$ Thus, regulatory supervision and enforcement is needed to ensure that the minority shareholders are afforded protection.

\section{EQUAL TREATMENT OF SHAREHOLDERS}

In relation to the foundation of take-overs regulation, the 2016 Code reproduces what was contained in the 2010 Code in the matter of shareholders' protection. At the heart of the objective of protecting shareholders is the principle of equal treatment of all shareholders. The rule on equal treatment of shareholders is a transplant from the English take-overs law. The equal treatment of shareholders has been extensively discussed in academic works. Basically, the principle of equal treatment for all shareholders requires firstly, that the same information are afforded to all shareholders of the target company and secondly, that an equivalent offer value is extended to all shareholders.

8 A transaction to acquire control, or consolidate voting rights, or voting power, howsoever effected including by way of a trust scheme, scheme of arrangement, compromise, amalgamation or selective capital reduction and repayment.

9 Paul Davies, "Control Shifts via share Acquisition Contracts with Shareholders", paper presented at Comparative Takeover Conference, National University of Singapore in July 2015. 


\section{DUTY OF GOOD FAITH BY THE BOARD OF DIRECTORS}

The duties of directors which flow from the Code mirrors the objectives of the law as specified in the CMSA 2007. ${ }^{10}$ These include the duty to act in good faith to observe the objects specified by the Act and that minority shareholders are not subject to oppression or disadvantaged by the treatment and conduct of the directors of the target company or the bidder. ${ }^{11}$ In order to ensure that the board of the directors of the target observes their duties to the shareholders of the target, the Rules make it clear that no directors should resign until the first closing date of the take-over or the date when the take-over offer becomes or is declared wholly unconditional. The same rule applies to the board of the directors once a bona fide offer has been communicated to the board of the target or they have reason to believe that a bona fide offer is imminent.

\section{COMPETENT INDEPENDENT ADVISER}

The 2016 Code imposes an obligation upon the board of the target, upon receiving an offer or upon being approached with a view to an offer being made, to appoint a competent independent adviser. ${ }^{13}$ The appointment of the independent adviser aims at enabling the shareholders of the target to arrive at an informed decision relating to the merits of the offer made. The Rules require the preparation of an independent advice circular, in any take-over exercise or where exemptions are sought based on fairness and reasonableness of the exemption leading to the mandatory offer obligation. In both circumstances, the Rules require that the recommendation to accept or reject the offer must be made based on the parameters as provided in the Rules. ${ }^{14}$ With the close guidance given to independent advisers on the preparation of the advice circular, it is hoped that the quality of the circular is enhanced and the shareholders of the target company will benefit from the advice given by the advisers.

Section 217(5)(d) of the CMSA.

General Principle $2 \& 8$ of the 2016 Code.

15.2, the Rules.

General Principle 4 of the 2016 Code.

Schedule 2: Part $1 \& 2$ of the Rules. 


\section{ANTI-EVASION: 'ACTING IN CONCERT RULE'}

Malaysia adopts a mandatory offer bid rule, the object of which is the protection of minority shareholders. The purpose of the rule is to allow the remaining shareholders in the target company to exit the company at the price which the bidder paid for upon a change of control of the company. This rule, thus prevents locking in the shareholders of the target company without giving them an opportunity to decide on the control. A person is presumed to have the control of the company where he holds more than 33 percent shares of the target. Some parties avoid the rule by splitting the shareholding into small chunks below the "control threshold" figure. The evasion is done by separating the purchase in time and by different persons. The 2016 Code, similar to its predecessors, include an extensive set of relationships that may be included within the concept of acting in concert. There are, however, enhancements in relation to specification of parties acting in concert in REITs and business trusts. Where the bidder is a REIT, persons who come under the presumption of parties acting in concert include its management company, the director (together with his spouse, close relatives and related trusts), any person who owns or controls $20 \%$ of the voting shares of the management company, any person who is related to its associate or management company and its trustee. ${ }^{15}$ It is to be noted that in relation to a professional trustee, the concert party relationship is limited to the trustee (including its directors) acting in the capacity as trustee of the REIT. ${ }^{16}$ Where the bidder is a business trust, persons presumed to be parties acting in concert include its management company, its trustee-manager including the agent, a director of the trustee-manager (together with his spouse, close relatives and related trusts), any person who owns or controls $20 \%$ of the voting shares and any person who is related to an associate of the trustee-manager. ${ }^{17}$ The inclusion of these specifications provide for greater clarity on categories of concert party in relation to REITs and business trusts. 


\section{TAKE-OVER SCHEMES}

One of the most glaring changes introduced by the law is in relation to takeover schemes. A scheme of arrangement is a process in which a shareholder makes a capital repayment to other shareholders of the company, resulting in the majority shareholder owning $100 \%$ control of the company. There are a variety of schemes of arrangement which can be effected by the controlling shareholders. For a valid scheme of arrangement, the law requires $75 \%$ of non-interested shareholders to approve after which approval of the court must be obtained. Unlike the previous position which requires a holder to have a 50\% shareholding or more before embarking on a scheme of arrangement, the Rules currently allow shareholders owning between $33 \%$ and $50 \%$ of equity interest in the company to embark on such scheme. In other words, under the current law, a scheme can be launched by those holding less than $50 \%$ equity interest in the company. In contrast to the previous law, a 'white knight' who wants to rescue a company does not need to be a major shareholder of the target company. The current law removes the obstacle faced by a white knight to search for large funds as it was in the past or to set up a special purpose vehicle to acquire $50 \%$ equity interest in the target company.

\section{BOARD NEUTRALITY AND SHAREHOLDER EMPOWERMENT}

General Principle 11 reiterates the principle that prohibits company directors of the target from taking any action that would frustrate a take-over offer, in the event of an offer or imminent offer, without prior approval from the shareholders. ${ }^{18}$ Circumstances which may lead to frustration of a takeover offer are clearly spelt out in the Rules. ${ }^{19}$ A takeover offer can be frustrated where the act of the board of the target results in the dilution of the shareholding of the bidder or makes it difficult or more expensive for the bidder to obtain control in the target. The Rules lists down a wide number of actions that may amount to frustration of the offer. Declaration of dividends other than the normal course and the usual quantum can also amount to

\footnotetext{
18 See also Rule 16 of the Rules.

19 Ibid.
} 
frustration of a takeover offer. ${ }^{20}$ Other actions which constitute frustration of the offer among others, include issuance of shares or granting of options in respect of unissued shares, selling of the 'crown jewel', the selling of treasury shares into the market and the entering into contract other than in the ordinary course of business.

\section{CONCLUDING REMARKS}

Corporate control transactions occur today in various different shapes. Takeover laws are put in place to ensure an orderly process of change in control and protection for the shareholders. The revision of the framework for the takeovers and mergers law via the introduction of the 2016 Code has brought Malaysia closer to the approach taken by advanced countries. The 2016 amendments also reflect the revisions made to the Capital Market and Services Act in 2015 for a more dynamic regulatory environment for takeovers. The 2016 Code which prescribes a set of 12 general principles to be observed in takeovers and mergers provide comprehensive rules for those involved in the corporate exercise. The Rules on the other hand serve as a detailed guidance in relation to takeovers and mergers transactions. The Rules also provide clarity to the general principles contained in the Code; replacing the practice notes under the previous takeover regime. Nevertheless, close supervision is needed especially when new rules are introduced. The current rule that enables shareholders with a lower shareholding percentage to launch a scheme of arrangement may give rise to concern in relation to abuse by majority shareholders. It needs to be acknowledged, however that law and regulations must be facilitative to commercial realities.

$20 \quad$ Rule $16.01(2)(\mathrm{g})$. 